\title{
The Influence of Gender on Assertiveness, Behavior Control, Peers Social Skills and Task Orientation Of Preschoolers Aged 5-6
}

Adela-Simina Câmpan, Mușata Bocoș 


\title{
The Influence of Gender on Assertiveness, Behavior Control, Peers Social Skills and Task Orientation Of Preschoolers Aged 5-6
}

\author{
Adela-Simina Câmpan ${ }^{a^{*}}$, Mușata Bocoș ${ }^{b}$ \\ ${ }^{a, b}$ Faculty of Psychology and Educational Sciences, Babeș-Bolyai University, 7 Sindicatelor Street, Cluj-Napoca, 400029, Romania \\ *Corresponding author: adela.campan@yahoo.com
}

\section{Abstract}

Keywords:

early education; outdoor education; gender; personal and social development; performance
Outdoor education begins beyond the door of the classroom and promotes outdoor learning. Because it takes place in the natural environment, outdoor activities are more attractive, more appreciated by children, for which they are more motivated to become actively involved in the proposed work tasks. The research proposed and carried out by us aims to investigate the training and informative valences of an educational intervention program based on outdoor type experiential activities in preschool education, ages 5-6. Although this concept is at the beginning of the road in Romania, studies conducted abroad and the educational reality of other education systems have shown that outdoor education has many benefits for educators of all ages. Our research aims to highlight the impact of experiential outdoor activities on preschoolers. The present article aims to verify whether there are significant differences in gender regarding assertive behavior, behavior control, peer social skills and task orientation.

\section{Zusammenfasung}

Schlüsselworte:

Früherziehung;

Outdoor-Bildung;

Geschlecht; persönliche

und soziale

Entwicklung; Leistung
Der Outdoor-Erziehung beginnt außerhalb der Tür des Gruppenraums und fördert das Lernen im Freien. Da sie in einer natürlichen Umgebung stattfinden, sind Aktivitäten im Freien attraktiver, werden von den Kindern mehr geschätzt, von denen sie sind motivierter, sich aktiv an den vorgeschlagenen Aufgaben zu beteiligen. Die Forschung, die von uns vorgebracht und durchgeführt wurde, zielt darauf $\mathrm{ab}$, die formativen und informativen Valenzen eines pädagogischen Interventionsprogramms zu untersuchen, das auf experimentellen Aktivitäten des Typs Outdoor in der Vorschulerziehung für die große Gruppe basiert. Obwohl dieses Konzept in Rumänien im Anfangsstadium ist, haben im Ausland durchgeführte Studien und die pädagogische Realität anderer Bildungssysteme gezeigt, dass die OutdoorErziehung viele Vorteile für Lernende aus allen Altersstufen hat. Unsere Forschung zielt darauf ab, die Auswirkungen von Outdoor-Aktivitäten auf Vorschulkinder zu untersuchen. Der vorliegende Artikel soll überprüfen, ob es signifikante Unterschiede im biologischen Geschlecht hinsichtlich des Durchsetzungsverhaltens, der Selbstkontrolle, der sozialen Fähigkeiten und der Arbeitsorientierung gibt.

\section{Introduction}

Education, as a process of training and informing the individual, has been and remains the main task of educational institutions. Although it is a lifelong process, without overlapping exclusively the schooling period, kindergarten and school are responsible for forming and developing autonomous and creative personalities, ready for successful integration into society. Even if the educational process is usually carried out in the classroom, we must not limit ourselves to this space, but take into account the fact that there are many other situations or environments beyond the group/ class door, which can provide learning experiences to children/students, exploiting their potential.

Outdoor activities that can be carried out successfully with preschoolers (especially ages 5-6) are: excursions, sports activities, various games, practical-household activities, creative workshops, learning activities adapted to the external environment. Each such activity tries to put preschoolers in a position to collaborate with colleagues, to find solutions, to develop their creativity, to strengthen their self-confidence in completing the task and to achieve the expected result.

\section{Theoretical foundation}

The praxiological dictionary of pedagogy defines outdoor activities as "activities that promote outdoor learning, recreational and fun activities, personal and social development programs, nature trips, mountain trips, environmental education, etc. Thus, these activities have the following main characteristics: they offer the possibility of direct contact with nature, of living experiences in nature; stimulate the joy of staying in nature; support the learning process of students with various learning difficulties; develop team spirit, self-help and fairplay; they offer countless physical, emotional, mental benefits, which subsequently contribute to the 
well-being of the individual and the group". (Bocoș, 2016, p. 43).

In our opinion, outdoor activities are outdoor learning activities that involve practical learning experiences, aimed at training and developing the skills of the participants, as well as acquiring knowledge and applying them, capitalizing on the resources of the natural environment.

Of all the characteristics of outdoor education, the most important refers to the place of development: the natural environment. The name of this concept, „outdoor education", indicates the different location from the usual educational environments. The natural environment offers many learning opportunities, but it also requires knowledge of certain information and skills.

Compared to the traditional classroom, the outdoor environment has its own characteristics:

- by participating in outdoor activities, children/ students are exposed to possible risks (for example: harsh weather, possible medical events or accidents regarding the transportation of participants, etc.);

- teaching outdoors requires certain skills from the teacher (for example, teachers must be prepared at all times to manage risks or possible accidents);

- outdoor activities often require equipment and certain materials;

- teaching in outdoor activities requires a longer period of time than in the classroom, more effort and sometimes involves higher costs.

The outdoor activities aim at effective learning environments, valorise the experiences of the participants in the learning process and develop the sensitivity of children/ students to the environment. According to Gair (apud Gilbertson, Bates, McLaughlin and Ewert, 2006), education in the natural environment encourages the development of relationships, the development of new interests and skills, and facilitates the connection between theoretical and practical knowledge, aspects that are sometimes neglected in the traditional curriculum. Outdoor activities connect the "to know" and "to do", highlighting the importance of practical experience.

Outdoor education is based on experiential learning. This aspect has been highlighted over time by educators such as Comenius, Rousseau, Pestalozzi and Dewey. The importance of action-based learning, the child's ability to interact directly with the environment for developing strategies and finding solutions to solve the task, regardless of its nature, is highlighted by L. B. Sharp (1943), a pioneer of outdoor education: "What can be learned best inside classrooms, there should be taught, and what can be learned best through experience, operating directly with indigenous materials and life situations outside of school, there should be learned". (Educational Project Outdoor Education, 2016).

In this context, great importance is given to children's experiences, real-life experiences, which underlie learning. They can be carried out in both school and nature (parks, courtyards, botanical gardens, etc.), but the exploitation of the child's potential, his involvement and the achievement of the expected results will be more pronounced outside the educational institution, primarily due to the more attractive nature of the proposed activities.

Outdoor education:

- is experiential;

- takes place outside the classroom (,out-of doors”);

- appeals to all senses and fields of knowledge;

- is based on an interdisciplinary curriculum (there is a transfer between the knowledge belonging to the different fields of knowledge, the theoretical knowledge is applied for a better understanding);

- exploits the interrelations (educable-educable, educable-teacher, educable-natural resources).

Through its specificity, outdoor education contributes to the personal and social development of the child, appealing to the senses and to forming and developing a solid relationship with the surrounding nature (this benefit both the individual and the entire community). Through the research undertaken, we wanted to highlight the formative valences of outdoor activities and their impact on both the personal and social development of the preschool (assertiveness, behaviour control, peer social skills), as well as on the preschoolers' performances (task orientation).

\section{Research methodology}

The purpose of this research is to study the impact of organizing outdoor activities on the personal and social development of pre-schoolers (assertiveness, behaviour control, peer social skills) and on their school performance (task orientation). 
The experimental approach aims to verify the following hypothesis:

There are significant differences at the gender level regarding assertiveness, behaviour control, peer social skills and task orientation.

The research variables are:

Independent variable:

- organizing and conducting by the teacher for the preschool education a system of experiential activities of outdoor type, while complying with the curriculum for preschool education;

Dependent variables:

- the level of assertiveness;

- the degree of behaviour control;

- availability to form peer social skills;

- the degree of task orientation.

The methods used by us in conducting the research are the psycho-pedagogical experiment and the observation method. The participatory observation made was carried out in natural observation situations, using, as a research tool, the Teacher-Child Rating Scale (T-CRS) 2.1. Teacher-Child Rating Scale (T-CRS) 2.1., made by Hightower and Perkins, is a concise scale of objective assessment, specially designed for use by teachers to evaluate children's behaviour and the school difficulties they face. This scale is composed of 32 items and evaluates the preschoolers' task orientation, behaviour control, assertiveness and peer social skills.

In the case of the proposed research, a sample of 104 large preschools (5-6 years) and 6 teachers, from 4 state and private preschool units (one group from each unit), with an extended program, from Cluj and Sălaj counties, was involved.

The sample of content valorised in the accomplishment of the formative experiment aims at outdoor type experiential activities, focused on the experiential domains with which the Curriculum for the preschool education (2008) operates and, starting with the 2019-2020 school year, the Curriculum for early education (2019).

The proposed activities took place between October 2018 - May 2019 (except holidays), once a week, these being integrated into the daily program of preschoolers.

\section{Results}

Table 1. Descriptive statistics

\begin{tabular}{cllll}
\hline Gender & Assertiveness & $\begin{array}{l}\text { Behavior } \\
\text { control }\end{array}$ & $\begin{array}{c}\text { Peer social } \\
\text { skills }\end{array}$ & Task orientation \\
\hline \multirow{2}{*}{ Boys } & $\mathrm{M}=25.63$ & $\mathrm{M}=26.92$ & $\mathrm{M}=27.45$ & $\mathrm{M}=26.87$ \\
& $\mathrm{AS}=6.51$ & $\mathrm{AS}=6.44$ & $\mathrm{AS}=6.79$ & $\mathrm{AS}=6.72$ \\
\hline \multirow{2}{*}{ Girls } & $\mathrm{M}=28.16$ & $\mathrm{M}=29.91$ & $\mathrm{M}=30.89$ & $\mathrm{M}=30.67$ \\
& $\mathrm{AS}=5.33$ & $\mathrm{AS}=5.51$ & $\mathrm{AS}=5.86$ & $\mathrm{AS}=6.27$ \\
\hline \multirow{2}{*}{ Total } & $\mathrm{M}=26.97$ & $\mathrm{M}=28.50$ & $\mathrm{M}=29.27$ & $\mathrm{M}=28.88$ \\
& $\mathrm{AS}=6.02$ & $\mathrm{AS}=6.13$ & $\mathrm{AS}=6.51$ & $\mathrm{AS}=6.73$ \\
\hline
\end{tabular}


Table 2. Pearson correlation coefficients and coefficients of determination

for measured variables

\begin{tabular}{|c|c|c|c|c|c|}
\hline Variable & $\begin{array}{c}1 \\
\left(\mathbf{R}^{2}\right)\end{array}$ & $\begin{array}{c}2 \\
\left(\mathbf{R}^{2}\right)\end{array}$ & $\begin{array}{c}3 \\
\left(\mathbf{R}^{2}\right)\end{array}$ & $\begin{array}{c}4 \\
\left(R^{2}\right)\end{array}$ & $\begin{array}{c}5 \\
\left(R^{2}\right)\end{array}$ \\
\hline
\end{tabular}

\section{Assertiveness}

\section{Behavior control -.02}

\begin{tabular}{lll}
\hline 3. Peer social skills & $.65^{* *}$ & $.42^{*}$ \\
& $(.42)$ & $(.17$
\end{tabular}

\begin{tabular}{lllll}
\hline 4. Task orientation & $.68^{* *}$ & $.22^{*}$ & $.67^{* *}$ & - \\
& $(.46)$ & $(.05)$ & $(.45)$ & \\
\hline 5. Gender & $.21^{*}$ & $.24^{*}$ & $.26^{* *}$ & $.28^{* *}$ \\
& $(.04)$ & $(.06)$ & $(.07)$ & $(.08)$ \\
\hline
\end{tabular}

${ }^{* *}$ Correlation is significant at the 0.01 level
${ }^{*}$ Correlation is significant at the 0.05 level

Noting the table 1, we find the following: girls are more assertive than boys, $(\mathrm{M}=28.16, \mathrm{AS}=5.33$ versus $\mathrm{M}=25.63$, $\mathrm{AS}=6.51$ ), they have better self-control than boys $(\mathrm{M}=29.91, \mathrm{AS}=5.51$ versus $\mathrm{M}=26.92, \mathrm{AS}=6.44)$, they present a greater willingness to train social skills than boys $(\mathrm{M}=30.89, \mathrm{AS}=5.86$ versus $\mathrm{M}=27.45, \mathrm{AS}=6.79)$ and have a higher degree of task orientation than boys $(\mathrm{M}=30.67$, $\mathrm{AS}=6.27$ versus $\mathrm{M}=26.87, \mathrm{AS}=6.72$ ). We mention that of the 104 preschool participants, 49 are boys and 55 are girls.

Analyzing table 2, we notice that there are significant correlations between the measured variables:

- a correlation coefficient $\mathrm{r}_{(102)}=.65, \mathrm{p}<0.01, \mathrm{R}^{2}=.42$ was obtained between peer social skills and assertiveness ( $42 \%$ of the variance of the peer social skills variable is explained by the variable assertiveness);

- a correlation coefficient $\mathrm{r}_{(102)}=.42, \mathrm{p}<0.01, \mathrm{R}^{2}=.17$ was obtained between peer social skills and behavior control $(17 \%$ of the variance of the peer social skills variable is explained by the variable behavior control);

- a correlation coefficient $\mathrm{r}_{(102)}=.68, \mathrm{p}<0.01, \mathrm{R}^{2}=.46$ was obtained between task orientation and assertiveness ( $46 \%$ of the variance of the task orientation variable is explained by the assertiveness variable);

- a correlation coefficient $\mathrm{r}_{(102)}=.22, \mathrm{p}<0.05, \mathrm{R}^{2}=.05$ was obtained between task orientation and behavior control ( $5 \%$ of the variance of the task orientation variable is explained by the behavior control variable);
- a correlation coefficient $\mathrm{r}_{(102)}=.67, \mathrm{p}<0.01, \mathrm{R}^{2}=.45$ was obtained between the orientation task and the peer social skills $(45 \%$ of the variance of the task orientation variable is explained by the peer social skills variable).

Considering Cohen's (1988) criteria, we can say that gender is a predictor variable in the development of the following abilities: assertiveness $\left(\mathrm{R}^{2}=.04\right.$, that is $4 \%$ of the variance of the gender variable is explained by the assertiveness variable), behavior control $\left(\mathrm{R}^{2}=.06\right.$, that is $6 \%$ of the variance of the gender variable is explained by the behavior control variable), peer social skills $\left(\mathrm{R}^{2}=.07\right.$, that is $7 \%$ of the variance of the gender variable is explained by the peer social skills variable) and task orientation $\left(\mathrm{R}^{2}=.08\right.$, that is $8 \%$ of the variance of the gender variable is explained by the task orientation variable). After calculating the coefficients of determination, it is found that the relationship between the gender and the measured variables is a moderate one. Therefore, the hypothesis is confirmed.

\section{Conclusions}

As a result of the study, we find that, in our case, there are gender differences in terms of: assertiveness, behavior control, peer social skills and task orientation. Girls have developed these skills better than boys. Analyzing the data obtained, we find that the largest difference between the means is identified in the case of task orientation, while 
the smallest difference is found in the case of assertiveness.

We consider that the relatively small number of preschoolers participating in the study may be a limitation of this research. A larger sample of participants would be an advantage in testing such a hypothesis. Also, in our study all preschoolers come from urban areas. We consider that it would be recommended to carry out such a study with preschool participants from rural areas and, subsequently, to make a comparison.

Another educational recommendation is related to the verification of this hypothesis at other age levels (primary, high school, high school and even at university level). In addition, it would be interesting and useful to add the motivation variable in a similar study and see to what extent the level of motivation changes depending on the gender.

\section{Acknowledgments}

This work was possible with the financial support of the Operational Programme Human Capital 2014-2020, under the project number POCU 123793 with the title „Researcher, future entrepreneur - New Generation”.

\section{Authors note:}

The authors have equal contributions to this article.

Adela-Simina Câmpan is teacher for preschool education at Kindergarten with extended program "Linden perfume" Cluj-Napoca and PhD Student at Faculty of Psychology and Sciences of Education (Babeș-Bolyai University, Cluj-Napoca, Romania). Her research areas are oriented towards investigating the formative and informative valences of the outdoor type experiential activities in preschool education.

Mușata Bocoş is University Professor and Ph.D. Coordinator at the Faculty of Psychology and Sciences of Education (Babeş-Bolyai University, Cluj-Napoca, Romania). She has obtained a Ph.D. in Educational Sciences in 1997 at Babeș-Bolyai University. Her research interests are reflected in a series of studies and articles published in important national and international journals. Her teaching activity covers several domains such as the theory and methodology of curriculum, general didactics, and educational research.

\section{References}

Bocoș, M.-D., Răduț-Taciu, R., Stan, C. (2016). Dicționar Praxiologic de pedagogie - Volumul II (E-H). Pitești: Editura Paralela 45.
Gilbertson, K., Bates, T., McLaughlin, T., \& Ewert, A. (2006). Outdoor education. Methods and strategies. Champaign, IL: Human Kinetics.

*** Ministerul Educației Naționale. (2019). Curriculum pentru educația timpurie. Available at: https://www.edu.ro/sites/default/files/Curriculum\%20ET 20 19_aug.pdf (accessed at 17.09.2019).

*** Educational Project Outdoor Education (2016). Applicant Association of Preschool Parents of Little house with stories Kindergarten in Bistrița, project approved and funded by the County Council.

*** Curriculum pentru învăţământul preşcolar (3-6/7 ani). (2008). Available at: http://www.isj.albanet.ro/_documente/078_curriculu prescolar_2008.pdf (accessed at 10.02.2019). 